Jurnal Pemberdayaan: Publikasi Hasil Pengabdian kepada Masyarakat

Vol. 2, No. 2, Agustus 2018, Hal. 291-296

ISSN: 2088 4559; e-ISSN: XXXX-XXXX

DOI:

\title{
PENGUATAN FUNGSI DPS DALAM IMPLEMENTASI PRINSIP SYARIAH PADA BTM DAN BMT MILIK MUHAMMADIYAH DAERAH ISTIMEWA YOGYAKARTA
}

\author{
Riduwan $^{1}$, Priyono Puji Prasetyo ${ }^{2}$, Mufti Alam Adha ${ }^{3}$ \\ Universitas Ahmad Dahlan, Jalan Ring Road Selatan, Tamanan, Banguntapan, Bantul Yogyakarta \\ $55166^{1,2,3}$ \\ Email: mufti.alamadha@gmail.com
}

\begin{abstract}
ABSTRAK
Lahirnya Baitut Tamwil Muhammadiyah (BTM) atau Baitul Maal wa Tamwil (BMT) di lingkungan Muhammadiyah menjadi bagian penting dalam kemandirian ekonomi Muhammadiyah. BTM dan BMT merupakan lembaga keuangan mikro dengan prinsip syariah. Kegiatan utamanya terdiri pada dua bidang, yaitu bidang sosial (Baitul Maal) dan bidang bisnis (Baitul Tamwil). Sebagai lembaga keuangan Syariah, BTM dan BMT harus mendapat pengawasan yang layak, yang dilakukan oleh Dewan Pengawas Syariah. Kegiatan pengabdian kepada masyarakat dilakukan pada hari Jum'at dan Sabtu, tanggal 23-24 Maret 2018 yang bertempat di Aula Gedung PWM, Gedong Kuning, Yogyakarta. Peserta yang mengikuti kegiatan pengabdian ini berjumlah 45 orang yang berasal dari berbagai BTM dan BMT milik Muhammadiyah di Daerah Istimewa Yogyakarta. Peserta yang mengikuti pelatihan merupakan Dewan Pengawas Syariah dan Pengurus pada BMT dan BTM tersebut.
\end{abstract}

Kata kunci: Baitut Tamwil Muhammadiyah, Baitul Maal wa Tamwil, syariah

\begin{abstract}
The birth of the Baitut Tamwil Muhammadiyah (BTM) or the Baitul Maal wa Tamwil (BMT) in the Muhammadiyah environment became an important part of Muhammadiyah's economic independence. BTM and BMT are microfinance institutions with sharia principles. The main activity consists of two fields, namely the social sector (Baitul Maal) and the business field (Baitul Tamwil). As a Sharia financial institution, BTM and BMT must receive proper supervision, carried out by the Sharia Supervisory Board. The community service activities were held on Friday and Saturday, March 23-24 2018 which took place at the Hall of the PWM Building, Gedong Kuning, Yogyakarta. The participants who participated in this service activity were 45 people from various BTM and BMTs belonging to Muhammadiyah in the Special Region of Yogyakarta. Participants who took part in the training were the Sharia Supervisory Board and the Management of the BMT and BTM.
\end{abstract}

Keywords: Baitut Tamwil Muhammadiyah, Baitul Maal wa Tamwil, syariah 


\section{PENDAHULUAN}

Melalui muktamar Muhammadiyah tahun 2015 di Makasar, ekonomi telah ditetapkan menjadi pilar ketiga dakwah Muhammadiyah, disamping pendidikan, sosial dan kesehatan. Bidang ekonomi diharapkan mampu mendorong lahirnya pengusaha Muhammadiyah yang mandiri dan tangguh, disamping juga menjadi sumber pendanaan dakwah Muhamadiyah. Dari bidang ekonomi ini pula Muhammadiyah akan menjadi organisasi yang mandiri.

Lahirnya Baitut Tamwil Muhammadiyah (BTM) atau Baitul Maal wa Tamwil (BMT) dilingkungan Muhammadiyah menjadi bagian penting dalam kemandirian tersebut. Gerakan BTM dan BMT di Muhammadiyah sesungguhnya sudah dimulai sejak Muktamar tahun 2000 di Jakarta. BTM dan BMT merupakan lembaga keuangan mikro dengan prinsip syariah. Kegiatan utamanya terdiri dau bidang yaitu bidang sosial (Baitul Maal) dan bidang bisnis (Baitul Tamwil). Bidang sosial bergerak dalam menghimpun dana zakat, infaq, sedekah, wakaf (Ziswaf) dan dana sosial lainnya serta menyalurkanya kepada yang berhak (mustahik). Prioritas bidang sosial ini adalah produktifitas dana Ziswaf menuju kemandirian mustahik. Fungsi sosial dari BTM dan BMT merupakan fungsi Lembaga Amil Zakat (LAZ). Dalam konteks Muhammadiyah, maka fungsi sosial BTM dan BMT dikerjasamankan dengan Lembaga Amil Zakat Muhammadiyah (Lazismu).

Sebagai lembaga keuangan syariah, BTM dan BMT harus mendapat pengawasan yang layak, sehingga implementasi prinsip syariah dapat berjalan dengan baik. Pengawasan syariah harus dilakukan oleh badan yang memiliki kompetensi dibidangnya. Badan ini disebut dengan Dewan Pengawas Syariah (DPS). DPS di BTM dan BMT berasal dari Majelis Tabligh atau Tarjih Muhammadiyah sesuai dengan tingkatan BTM dan BMT yang didirikan, dengan tingkatan terendah berada pada Pimpinan Cabang Muhammadiyah dan tingkatan tertinggi pada Pimpinan Wilayah Muhammadiyah.

Fungsi DPS sesungguhnya sangat strategis, karena menyangkut kepentingan umat untuk menghindari riba dalam setiap aktivitas ekonomi dan bisnisnya. Maka dari itu, DPS merupakan lembaga yang paling bertanggungjawab terhadap implemenasi prinsip syariah pada lembaga keuangan syariah. Pengawasan DPS pada BTM dan BMT, akan meningkatkan kepatuhan syariah dan akhirnya akan mendorong kepercayaan anggota. Tingginya kepercayaan anggota akan berpengaruh terhadap peningkatan kinerja BTM dan BMT.

Melihat fungsi DPS yang sangat strategis tersebut, maka DPS pada BTM dan BMT dilingkungan Muhammadiyah, merupakan representasi dari Majelis Tabligh atau Tarjih disemua 
tingkatan. Kemampuan DPS dalam mengawasi pelaksanaan prinsip syariah, menjadi tanggungjawab kolektif majelis tersebut. Oleh sebab itu, diperlukan peningkatan kapasitas pengawasan DPS, sehingga implementasi syariahnya dapat berjalan dengan baik.

\section{METODE}

Kegiatan ini dilaksanakan dua hari yaitu pada hari Jumat dan Sabtu tanggal 23 dan 24 Maret 2018 dari pukul 08.00-17.00 WIB. Peserta yang mengikuti pelatihan berjumlah 45 orang terdiri dari dewan pengawas syariah (DPS) dan pengurus pada BMT/BTM yang diundang. Tempat pelaksanaan kegiatan ini di gedung Aula PWM DIY Jalan Gedong Kuning Yogyakarta.

Khalayak sasaran kegiatan pengabdian kepada masyarakat bertujuan untuk meningkatkan pemahaman dewan pengawas syariah dalam menjalani tugasnya sebagai pengawas syariah pada BMT dan BTM. Kegiatan dilaksanakan bertempat di Aula Gedung Pimpinan Wilayah Muhammadiyah Yogyakarta dengan jumlah peserta yaitu 46 orang. Adapun yang menjadi instruktur dan narasumber dalam kegiatan ini adalah dosen-dosen Program Studi Perbankan Syariah yang memiliki pengalaman dalam menyampaikan materi yang berhubungan dengan BMT dan BTM.

Materi yang diberikan meliputi: Maqashid Syariah dan Implementasinya pada BTM-BMT; Peluang dan Tantangan BTM-BMT; Prinsip Syariah pada Lembaga Keuangan Mikro Syariah; Manajemen Keuangan pada Lembaga Keuangan Mikro; Riba dan Problematikanya pada Lembaga Keuangan Syariah; Fungsi DPS dalam pengawasan Syariah di BMT dan BTM; Bedah Akad BMTBTM; serta Laporan Pengawasan Syariah.

1. Latihan, Metode ini digunakan untuk memberikan tugas kepada peserta untuk menjawab pertanyaan yang diajukan oleh instruktur. Menilai sejauh mana pemahaman peserta terhadap materi yang disampaikan. Dan juga memberikan contoh studi kasus dan bagaimana penyelesaiannya dalam pemahaman oleh setiap peserta.

2. Ceramah dan dialog, diberikan pengantar dan arahan agar peserta memahami gambaran pelatihan dan target capaian;

3. Pemberian modul kepada peserta, sehingga peserta lebih mudah dalam menerima dan memahai materi yang diberikan, sehingga kegiatan ini lebih efektif;

4. Pemberian contoh dan kasus permasalahan, sehingga diharapkan peserta akan lebih memahami fungsi dan peran DPS pada BTM dan BMT di lingkungan Muhammadiyah; 
5. Evaluasi, Dilakukan evaluasi mengenai hasil dari pelatihan dan sosialisasi peran dan fungsi DPS pada BTM dan BMT.

\section{HASIL, PEMBAHASAN, DAN DAMPAK}

Pelaksanan kegiatan PPM ini dilakukan oleh 3 (tiga) orang tim pengabdi dengan pokok bahasan yang disampaikan mengenai:

1. Maqashid Syariah dan Implementasinya pada BMT-BTM

2. Peluang dan Tantangan BMT-BTM

3. Prinsip Syariah pada Lembaga Keuangan Mikro Syariah

4. Manajemen Keuangan pada Lembaga Keuangan Mikro

5. Riba dan Problematikanya pada Lembaga Keuangan Syariah

6. Fungsi DPS dalam Pengawasan Syariah di BMT-BTM

7. Bedah Akad BMT-BTM

8. Laporan Pengawasan Syariah

Keterbatasan waktu pertemuan mengakibatkan tidak semua materi dapat disampaikan dengan detil. Kegiatan yang diawali dengan ceramah dan demonstrasi ini kemudian dilanjutkan latihan. Dari kegiatan latihan tampak bahwa peserta tidak semuanya mampu menguasai, namun sebagian besar mampu menjawab atau merespon pertanyaan yang diberikan tentang materi dengan baik. Oleh karena itu mereka mengharapkan kegiatan ini dapat dilaksanakan secara berkala untuk merefresh dan meningkatkan pengetahuan mereka tentang tugas dan fungsi yang harus dilaksanakan di BTM/BMT. Acara kemudian dilanjutkan dengan sesi tanya jawab.

Hasil kegiatan PPM secara garis besar mencakup beberapa komponen sebagai berikut:

a) Keberhasilan target jumlah peserta pelatihan

b) Ketercapaian tujuan pelatihan

c) Ketercapaian target materi yang telah direncanakan

d) Kemampuan peserta dalam penguasaan materi

Target peserta pelatihan seperti direncanakan sebelumnya adalah paling tidak 50 Dewan Pengawas Syariah termasuk dengan pengurus BMT-BTM di Provinsi Yogyakarta. Dalam pelaksanaannya, kegiatan ini diikuti oleh 45 orang peserta dari beberapa BTM-BMT yang diberikan undalangan dalam kegiatan ini. Dengan demikian dapat dikatakan bahwa target peserta 
tercapai $100 \%$. Angka tersebut menunjukkan bahwa kegiatan PPM dilihat dari jumlah peserta yang mengikuti dapat dikatakan berhasil atau sukses secara berjumlah.

\section{SIMPULAN}

Program pelatihan peningkatan fungsi pengawasan syariah BMT dan BTM se DIY dapat diselenggarakan dengan baik dan berjalan dengan lancar sesuai dengan rencana kegiatan yang telah disusun meskipun tidak semua peserta pelatihan menguasai dengan maksimal materi yang disampaikan. Namun pemahaman peserta meningkat setelah mengikuti pelatihan ini, dilihat dari hasil diskusi, jawaan dan respon yang mereka berikan. Kegiatan ini mendapat sambutan sangat baik terbukti dengan keaktifan peserta mengikuti pelatihan dengan tidak meninggalkan tempat sebelum waktu pelatihan berakhir.

\section{DAFTAR PUSTAKA}

Huda, Nurul dan Mustafa Edwin Nasution, Current Issues Lembaga Keuangan Syari'ah, Kencana Predana Media Grup, Jakarta, 2009

Nasution, A. C. (2013). Efficiency of Baitul Maal Wa Tamwil (BMT): An Effort Towards Islamic Wealth Management in Microfinance Institution. In Proceeding of the 5th Islamic Economics System Conference (pp. 156-164).

Nurhasanah, Neneng, 2011. Optimalisasi Dewan Pengawas Syariah di Lembaha Keuangan Syariah. Jurnal Syiar Hukum Unisna, Vol. 8 (3), hal. 218-231.

Wulandari, Permata \& Kassim, Salina. 2016. Issues and Challenges in Financing the Poor: Case of Baitul Maal wa Tamwil in Indonesia. International Journal of Bank Marketing, Vol. $34(2)$. 